\title{
Aspects regarding the treatment of neologisms in DELR. Completing previous etymological explanations
}

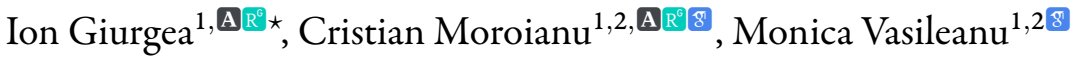 \\ 1 "Iorgu Iordan - Al. Rosetti" Institute of Linguistics, 13 Calea 13 Septembrie, 050711 Bucharest, Romania \\ ${ }^{2}$ Faculty of Letters, University of Bucharest, 5-7 Edgar Quinet St., 010017 Bucharest, Romania
}

Article info

History:

Received March 2, 2020

Accepted March 15, 2020

Published June 10, 2020

Key words:

etymology

neologism

borrowing

word formation

\begin{abstract}
This paper's authors, who are also authors and coordinators of DELR, discuss the etymological treatment of neologisms in Romanian academic dictionaries, with a special emphasis on words starting with the letters $A-D$. The paper comprises some original etymologies, completing and correcting the solutions previously proposed by DEX and DLR. This endeavour calls for a fresh overview of the main criteria used by lexicographers in scientific etymological research, and for a re-evaluation of several concepts such as multiple etymology or mixed etymology. The paper discusses the origins of 132 words and is organized according to the main criterion that underlay the authors' option for a certain etymological solution.
\end{abstract}

\section{Introduction}

The present paper presents a series of original solutions that correct and complete the etymological treatment of neologisms in Romanian academic dictionaries. Our solutions are based on the first three volumes of DELR (i.e. The Etymological Dictionary of Romanian), published in 2011, 2015 and 2018, and on the work-in-progress for the fourth volume and for the revised version of the first volume ${ }^{1}$.

In Romanian linguistics, the term "neologism" embraces both recent words and cultural terms that entered the language in the modern period (starting with the second half of the $18^{\text {th }}$ century).

Etymology is one of the most important aspects of the history of any language, for several reasons: (1) it sheds light on the past and present geographical and cultural contacts that the speakers of a language have had with other languages; (2) it lays the foundation for relevant statistics regarding the number and status of the words that constitute the lexicon of a language; (3) it reveals the tendencies in the evolution of the lexicon, in connection to the integration of a linguistic community in a broader cultural network.

It is well known that Romanian comprises words of quite various origins. On the one hand, Romanian has been substantially influenced throughout its history by languages such as Old Slavic, Bulgarian, Serbian, Turkish, Hungarian, German, and Ukrainian, via direct contact with speakers of these languages. On the other hand, Romanian has suffered many linguistic influences from languages of culture, via written texts (rather than oral communication): Church Slavonic, Latin, (Modern and Ancient) Greek, French, German (again), Italian, Russian, and English. Some of the afore-mentioned languages have partially or totally lost their status of donor languages. For instance, Modern Greek and Russian acted as donor languages only in certain periods and in certain socio-political contexts. Other languages, such as scholarly Latin, Italian and (more recently) Spanish, still contribute to the Romanian lexis in various ways. Latin has remained an important source language for scientific loanwords, whereas Italian and Spanish (MV).

^Email addresses: giurgeaion@yahoo.com (IG),cristian_moroianu@hotmail.com (CM),monica.vasileanu@gmail.com

${ }^{1}$ The first volume of is currently being reviewed and augmented in order to comply with the editing norms established in the latest volume ( $2^{\text {nd }}$ part of the $2^{\text {nd }}$ volume, published in 2018 , see the Bibliography). 
Ion Giurgea, Cristian Moroianu \& Monica Vasileanu

constitute the source for several words that name specific realities of the two cultures. Finally, English has now deepened its influence on the Romanian vocabulary in a specific socio-economic context similar to the one in which the French influence was exerted in the $19^{\text {th }}$ century, but different from the latter due to its global character.

Academic lexicography is especially concerned with finding the most plausible etymologies, i.e. the closest to the word-coining reality, and this can only be achieved by respecting specific scientific criteria (Sala, 1999, p. 23-32). In a nutshell, a certain foreign word (or several) may be considered as the etymon ${ }^{2}$ of a Romanian word if:

a) there is a clear formal (phonetic and morphological) and semantic correspondence between the two words (the formal criterion and the semantic criterion); the correspondence has to be evaluated also by taking into account the evolution of the Romanian word;

b) the alleged foreign etymon is attested in the donor language before its first attestation in Romanian (the chronological criterion $)^{3}$;

c) the alleged foreign etymon was currently in use in the donor language at the time when it was borrowed into Romanian (the etymon frequency criterion $)^{4}$;

d) in the case of oral loanwords, the direct etymon belongs to a language neighbouring the Romanian area where it was first attested (the geographic criterion);

e) the Romanian word belongs or used to belong to a language layer reflecting a certain cultural orientation. This orientation is confirmed by the cultural biographies of the authors that first used those specific words (the historical and cultural criterion).

In the case of words formed by word formation (derivation by affixes, compounding, lexical conversion), at least the following criteria have to be respected:

a) the formal criterion, i.e. the etymologist should be able to clearly identify the morphemes;

b) the derivational criterion, i.e. there should be an established compatibility between the affixes and the grammatical category of the stem ${ }^{5}$;

c) the criterion of the origin of the morphemes, according to which words formed with affixes whose origin is different from that of the stem can only rely on derivation inside the language at issue (here, Romanian);

d) the semantic criterion, i.e. the compositionality of meaning.

Finally, in the case of old or new cultural borrowings, the etymologists must consider the possibility of word formation inside Romanian on the model of one or more external sources, i.e. lexical or lexicogrammatical calque (loan translation). The criteria used for considering a certain word as an instance of calque are the chronological criterion and the historical and cultural one.

An important issue in Romanian etymology is the so-called multiple etymology, which can be external or mixed. The multiple etymology, as an objective fact (rather than a subjective indecision between several possible etymologies), refers to the situation of a word borrowed from two or more languages, either at the same time or at different moments, by different people or even by a single individual who

\footnotetext{
${ }^{2}$ We will further use 'etymon' for one or more foreign lexical units.

${ }^{3}$ Thus, for words that seem old, but are attested late, we must take into account the possibility of an external influence. In this case, the chronological criterion is complemented by the semantic and cultural ones. For instance, the verb a decădea 'to decay' is not simply derived in Romanian, but is a loanword from It. decadere and Fr. déchoir, both adapted on the model of the Ro. verb cădea 'to fall'. Ro. a descrește 'to decrease' was not formed from des- + crește independently, but it took on an external model: Fr. décroître.

${ }^{4}$ However, if a specific word belongs to a specialized language, its frequency in the donor language is no longer relevant. It might have just a handful of attestations both in the donor and in the target language. In this situation, the chronological criterion and the historical and cultural one are more relevant.

${ }^{5}$ For instance, as a general rule, in Romanian, the negative prefix ne- is never attached to a short infinitive or finite verb forms, the suffix $-b i l$ is attached only to verbs, the suffix -os is attached only to noun stems, etc. Some exceptions to these rules may be explained by analogy, see, for instance, the process of derivation by substitution described in Moroianu (2008, p. 194-206; 2009, p. 281-294).
} 
is familiar with the form of the word in more than one language (e.g., with a French word and its Latin etymon). This situation usually occurs with international words and is favoured by the coexistence of multiple cultural influences over a certain period or a certain area, or by the multilingual profile of a certain author $^{6}$. Multiple mixed etymology refers to situations when a certain word may be borrowed, coined in Romanian, or both (for different people/contexts). Thus, if there are no counterarguments pertaining to the chronological, semantic or etymon frequency criteria, the verbs derived with the prefix $r e$ - may equally be considered Romanian derivatives and analysable loanwords, usually from French, e.g. a reabona to renew a pass', attested at the end of the $19^{\text {th }}$ century, a reangaja 'to rehire', attested at the beginning of the past century, a recombina 'to recombine'. Likewise, recent adjectives and nouns containing the prefix anti- also allow for a double etymological interpretation, either as Romanian derivatives or as analysable loanwords, e.g. antiacademic 'anti-academic', attested in the 1960's. A number of neological verbs could have been derived from adjectives or nouns in Romanian, but the derivation may have just as well occurred in a different language (culturally or genetically related to Romanian) and the verbs could have been borrowed as such, e.g. a anagrama 'to anagrammatize' may be derived from anagramă 'anagram' or borrowed from Fr. anagrammer; a ancora 'to anchor' may come from ancoră 'anchor' or from It. ancorare; similar cases are a absenta 'to be absent', a absolutiza 'to absolutize', a accidenta 'to cause an accident', a clica 'to click'. Recent adjectives ending in -bil usually have a multiple mixed etymology: acordabil 'that may be accorded', ameliorabil 'that may improve', clasabil 'that may be classified', conectabil 'that may be connected', etc. The same holds from recent adjectives derived from toponyms (e.g. anatolian 'Anatolian': from Anatolia or from Fr. anatolien). In such cases, even if there is evidence for an external source, the possibility of creation inside Romanian cannot be ruled out. We must also take into account analogy. For instance, the adverb abruptamente 'abruptly' may be a loanword from Fr. abruptement, modified to fit a series of adverbs of Italian origin ending in -(a)mente, or it may be derived from the Ro. adjective abrupt, following the pattern of certamente, finalmente, totalmente, etc. Ro. amicabil, a variant of the word amiabil 'amiable', may be considered as either a borrowing from Lat. amicabilis, or as an adaptation of Fr. amiable, modelled after Ro. amic 'friend'. Likewise, a complecta, a form of the verb a completa 'to complete', is either a Romanian derivation from the adjective complect (= complet 'complete') or a borrowing of Rus. komplektovat'. Other examples with multiple mixed etymologies include the noun bioclimatolog 'bioclimatologist', that may be interpreted as a loanword from Fr. bioclimatologue or a back formation from Ro. bioclimatologie, the verb a climatiza 'to provide the best temperature and humidity level in a room, a borrowing from Fr. climatiser or a back formation from the Ro. noun climatizare, attested three decades before the verbs and much more frequently, and the noun clip 'video', a clipping from Ro. videoclip or a loanword from Engl. clip ${ }^{7}$.

The new format of DELR was spelled out and applied starting with the second part of the second volume (issued at the Romanian Academy Publishing House in 2018). In this new format, the decisions regarding etymologies rely on a wider linguistic database. In addition to the sources used in the previous volumes of DELR, namely critically interpreted lexicological and lexicographical data from the reference dictionaries (PEW, CDDE, DA/DLR, CADE, SDLR, CDER, DîlR etc.), fundamental works dedicated to the lexical influences undergone by Romanian, and academic journal articles, we now use a large electronic corpus of Romanian texts, covering all the domains and all the history of the Romanian language ${ }^{8}$.

\footnotetext{
${ }^{6}$ Multiple external etymology can also be found for etymological variants; thus, the variant chiarificațiune of the noun clarificație 'clarification' may be a borrowing from It. chiarificazione and also an adaptation of French clarification on the model of the inherited form chiar.

${ }^{7}$ See Hristea (1973a, p. 3-15). A word may have also been borrowed from two sources, thus having a multiple external etymology, and at the same time it may have been coined in Romanian, with the same meaning or with a different one. Such is the case of the noun aristocratism 'aristocratic attitude', attested in the mid-19 $9^{\text {th }}$ century (1859, Bălășescu, D. R.-Fr.), that may be traced back to Fr. aristocratisme, Rus. aristokratizm, and it could as well have been derived from the Ro. adjective aristocratic (by substituting the suffix).

${ }^{8}$ This corpus was compiled by the Lexicography Department within the "Iorgu Iordan - Al. Rosetti" Institute of Linguistics.
} 
Moreover, besides the Romanian corpus, we access various online corpora of dictionaries and primary sources in foreign languages. The benefits of this type of research are obvious. First of all, the corpus research allows for a fresh check-up of the previously identified first attestations of a word, establishing the exact form in which it appears and the meaning it had. Secondly, it permits the lexicographer a more accurate estimation of a word's first attestation, sometimes even decades or centuries before the ones indicated in other dictionaries. Moreover, the lexicographers can now verify with higher accuracy the semantic criterion, as well as the chronological criterion (to what extent an alleged etymon is attested before the Romanian word) and the etymon frequency criterion (the alleged etymon's diffusion in the source-language). The lexicographers can also trace back the history of a concept, including its creator (in the case of scientific words) and its use in various terminological fields. All these digital tools allow a deeper investigation into the history of words, and therefore a lexicographic decision that is more coherent and better argued, compared with the previous dictionaries.

In the following sections, we present several etymologies established by the team of DELR, by which we complete or correct the previous solutions provided by the Romanian academic dictionaries. Some of these etymologies have already been published in DELR, others are part of the unpublished workin-progress. Neologisms are usually given an etymology in academic dictionaries ${ }^{9}$. Therefore, in our argumentation we must refer to these previous etymological indications, and argue in favour of our own solution based on the criteria described above. Thus, our presentation is organized according to the main criterion that underlies our reasons to reject the previous solutions. Sections 2-6 comprise examples based on the formal, semantic, chronological, etymon frequency and concept history criterion. In Section 7 we present a few etymological solutions for words registered with 'unknown etymology' in academic dictionaries. In some cases, we mentioned the first attestation of words and their sources. The full reference of these sources can be found in the bibliography published in DELR, $2^{\text {nd }}$ volume, $2^{\text {nd }}$ part.

\section{The formal criterion}

The formal criterion (also called the phonetic criterion, Sala, 1999, p. 23-25) is the most obvious argument in favour of a certain etymon. It can also be a misleading clue, as will be shown below (see Section 3 ). The formal changes, be they phonetic or morphological ones, depend on the word's age (inherited word vs loanword) and on the type of contact (popular vs scholarly contact, spoken vs written contact). In the case of neologisms, formal differences between the etymon and the Romanian word are minor; normally, the differences regard the morphological adaptation and the rendering of phonemes foreign to Romanian. Nevertheless, there were some situations in which DELR identified new etymons for neologisms based on the formal criterion.

\subsection{Identifying direct etymons formally closer to the Romanian words}

For recent cultural borrowings, academic reference dictionaries almost always indicate a direct etymon, as expected since these borrowings come from well attested languages and display minor phonetic changes. In a few cases, when the direct etymon was uncertain, the previous academic dictionaries cited a related form, in a foreign language, with "cf." or "după" 'after'. The wider documentary database used by DELR enabled us to identify the direct etymons, which are formally closer to the Romanian words than the forms previously cited. For instance, for acipenserid 'sturgeon', DEX indicated a relation with Lat. acipenser (using the label "cf."), which is indeed the remote etymon of the Romanian word, via the Latin derivative Acipenseride (< acipenser / acupenser / aquipenser 'sturgeon') and Engl. acipenserid. Likewise, DEX connects the verb cașera 'to apply another layer of material on a paper for aesthetic purposes' to Fr. cacher 'to hide'. Indeed, this is the remote etymon of the Romanian word, but the direct etymon is the Germ. verb kaschieren, which explains the Romanian form. Romanian also has a verb cașura with the same meaning, which is a modification of cașera, influenced by haşura 'to hatch, hachure' (by means of folk etymology).

\footnotetext{
${ }^{9}$ Cases where the etymology is indicated as 'unknown' are extremely rare for neologisms.
} 
DEX records only the long infinitive caşurare and links it to the noun caşa 'soft woollen fabric, usually dyed in light colours', an etymology that should be rejected on both formal and semantic grounds.

The relation between the adjective antum 'ante-mortem' and the Latin preposition ante has been registered by DEX, but no direct etymon was provided. The etymon had already been identified by $\mathrm{DN}^{3}$, as the Fr. adjective anthume < [post] hume (borrowed from Lat. postumus, TLF), an instance of antonymic substitution. A similar case is the adjective caniculat (botanical term) 'canaliculate'. DEX indicates a relation with the Fr. cannelé 'fluted', a term of architecture. We were able to identify a direct etymon, closer to the Romanian word both formally and semantically, namely Fr. canniculé. This adjective has not been recorded in the main French dictionaries (TLF, Larousse), but is attested in Nouveau dictionnaire d'histoire naturelle, appliquée aux arts, vol. XXXIV, 1819, available online. Fr. canniculé was probably borrowed from the scientific Latin term canniculatus < canniculus 'little channel' < canna 'reed; pipe', cf. Engl. canniculated. The related word indicated by DEX, namely Fr. cannelé, can be traced back to Lat. canna 'reed', as well.

The noun caradriiformă 'charadriiforme', that is related, according to DEX, with the current French term charadriidés designating this order of birds, should be considered a loanword from Fr., Engl. charad-

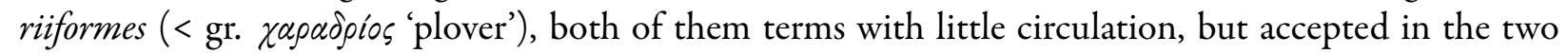
languages' taxonomic vocabulary. A similar example is the adjective monoclorurat '(about substances) that has received a chlorine atom, considered by DEX as formed "after Fr. monochloré", which suggests that the word was derived in Romanian. However, DELR identified a direct etymon, Fr. monochloruré, a word that went unrecorded in TLF or Larousse, but is attested in $19^{\text {th }}$ century books (e.g. Encyclographie des sciences médicales, Établissement Encyclographique, 1840, available online).

In the case of the noun cașa 'a soft woollen fabric', the etymon proposed by DEX has no etymological connection to the etymon identified by DELR. DEX suggests that there is a link ("cf.") with Germ. kaschieren 'to hide', a verb used in the terminology of the textile industry with the meaning 'to stick together two layers of fabric with a special glue'. But Ro. caşa is the direct offspring of Fr. kasha, a trademark formed from the words cachemire, Kashmir 'cashmere' (this etymology relies not only on formal, but also on historic and semantic arguments).

Sometimes, the etymon has several variants in the source language. For instance, Ro. ciclamă 'cyclamen' is deemed by DEX as coming from It. ciclamino, cf. Fr. cyclamen. In Italian, the flower is also called ciclamo or ciclame. The latter is an older form that was in use at the beginning of the $20^{\text {th }}$ century, when our word was borrowed, so it should be considered the direct etymon of our word. DELR also takes into account Fr. cyclame, an obsolete and more rare form of Fr. cyclamen, which yielded the Ro. form siclamă. Moreover, Germ. Zyklame is the direct etymon of the Ro. form ticlamă.

The choice for a certain etymon based on the formal criterion should rely also on the pronunciation rules. Thus, Ro. curry, pronounced ['kıri, 'k3ri], cannot be traced back to Fr. curry, as indicated in DEX, but was borrowed instead from Engl. curry (< Tamil kari'spicy sauce'), as DCR ${ }^{3}$ suggested.

\subsection{POS identity}

As a general rule, the etymon and the loanword should be the same part of speech (e.g., if a Romanian adjective has a French etymon, this etymon should be an adjective).

However, DEX indicates a noun, Fr. phytocénose, as the etymon of the adj. fitocenotic. This indication should be rejected on both phonetic and grammatical grounds. DELR states that the Romanian adjective was borrowed from the Fr. phytocénotique (alongside with MDA, s.v.), but does not reject the possibility of a Romanian derivation by means of suffix substitution from the noun fitocenoză (as previously indicated in $\mathrm{DN}^{3}$ ). We noticed a similar situation with the adjective topoclimatologic, which may be considered either a loanword from Fr. topoclimatologique (adj.), or a Romanian derivative of the noun topoclimatologie (both etymologies are accepted in DELR). But under no circumstances could it be a direct borrowing from the Fr. noun topoclimatologie. In both situations, we suspect some mere editing errors in DEX. 


\subsection{Correcting the form of the etymon}

Sometimes, the etymons indicated in our academic reference dictionaries have incorrect forms. In such situations, DELR corrects these forms or identifies other etymons that better satisfy the formal criterion.

Most of the times, the mistakes are minor and they might be mere editorial spelling errors. For instance, for the noun chernăr 'centre punch; sharp top of some tools', DEX indicates as etymon the Germ. Kerner, but the correct form of this word is Körner. Likewise, the noun colon 'currency in Costa Rica and El Salvador' is considered by DEX as originated from the Sp. colono. The correct form is colón, as the currency was named in honor of Christopher Columbus, whose Spanish name is Cristóbal Colón. The etymon of the Romanian word comans, 'Comanche' is, according to DEX, Fr. commanci, which is obviously a misspelling of the word Comanche. The French word comes, probably via Engl. Comanche, from Sp. comanche, a loanword from a Numic language (a branch of the Uzo-Aztecan family), where it meant 'foreigner'. The medical term pericimentită 'periodontitis' was considered by DLR a loanword from Fr. péricimentite. However, the French term is spelled péricémentite. The Romanian form was reshaped by speakers under the influence of the noun ciment, a variant of cement 'cement'. The source of the adjective protocarburat 'which forms a protocarbide' is indicated in DEX and DLR as Fr. protocarburat, but the correct spelling is protocarburé. An editorial error is to blame for the situation of Ro. combo 'combo', which is linked by DEX to Engl. combinaty (sic!). $\mathrm{DN}^{3}$ identified the correct etymon, namely Engl. combo, a word clipped from combination.

For the noun chalonă 'chalone', the situation is more complex. DEX recorded the word as chalon and recommended the pronunciation / Jalon/. In the etymological paragraph, DEX stated that it is a French word. However, in French the correct form is chalone, and its pronunciation is $/ \mathrm{kalon} /$. The Romanian word is in fact a feminine noun, chalonă or halonă, recorded as such in D.med. and in a few other texts that may be accessed online. In fact, the Romanian word comes from Fr. chalone and Engl. chalone. The latter was coined by the British physiologist Sir Sharpley Schäfer in 1913, based on Gr. $\chi \alpha \lambda \tilde{\alpha} \nu$ ' to let loose, to let go, to let fall', and the final part was modeled after hormone, see TLF and Keppel Hesselink (2015).

In other cases, DELR identified the correct etymons in other languages than those proposed by the reference dictionaries. For instance, for aduct 'adduct', the etymology provided by DEX is Fr. adducte ${ }^{10}$, but the French word is in fact adduit. That's why DELR indicated as a direct etymon Germ. Addukt (< Add[itionpro]dukt < Addition 'addition' + Produkt 'product' < Lat. productum, the perfect participle of the verb producere 'to produce') and Engl. adduct. Likewise, for the adjective circumvolut 'with circumvolutions', DEX suggests a French etymon, circonvolut. But the correct form of the French adjective is circonvoluté. Formally, Ro. circumvolut is a loanword from Lat. circumuolutus (the past participle of the verb circumuoluere 'to turn around, to swirl'), but the semantic evolution can only be explained by taking into account Fr. circonvoluté and Ro. circumvoluție 'circumvolution'. Another example is the noun fotocopier, a rare synonym of fotocopiator 'photocopier': DEX indicates a German etymon, Photokopier. But this word does not exist, as the German word is Photokopierer. Therefore DELR, relying on the formal criterion, accepted as etymons Fr. photocopieur and Engl. photocopier.

\subsection{Etymons explaining just one variant}

Sometimes, the etymon indicated in other dictionaries may be taken into account only for some of the lexical variants. Such is the case of the word calmuc 'Kalmuck; (Moldova) voracious'. DEX and TDRG ${ }^{2}$ consider that its origin is Rus. kalmyk. This is correct for the Ro. form calmîc, whereas the direct etymons of the form calmuc are the Turkish kalmuk and Fr. kalmouk (the latter was suggested by DA).

\footnotetext{
${ }^{10}$ This form was introduced in $\mathrm{DN}^{3}$ and perpetuated with no further check-ups even in MDA s.v., as Fr. aducte. Most of the wrong etymologies in DEX appear as such in MDA.
} 


\subsection{Word formation vs borrowing ${ }^{11}$}

The formal criterion may help etymologists decide whether a certain word was coined in Romanian or borrowed. Suffixes, for instance, are attached only to certain types of stems, and an etymology disregarding the restriction is implausible. The suffix -tor, for instance, creates agent names from verb stems. Therefore, the noun decimator 'the person who collects the tax called decimă' cannot be derived from the noun decimă, as proposed by DLR. There is no verb a decima 'to collect the tax called decimă, therefore the noun decimator should be considered a loanword from Lat. decimator < decimare 'to collect the tax called decimă. The same lexical family contains the noun decimație 'collection of the tax called decimă', which again cannot be derived in Romanian from the noun decim $\breve{a}$ (as indicated in DLR), but was borrowed from Lat. decimatio (< decimare). Likewise, he suffix -ibil attaches to verb stems, therefore the word conceptibil 'that may be conceived' cannot be formed from the noun concept 'concept', as proposed in DEX, but must be considered a loanword from Fr. conceptible.

The formal criterion may also argue in favour of derivation inside Romanian. For instance, for the adjective confundabil 'which may be confounded', the etymology proposed by DEX, namely It. confundibile (sic!), must be dismissed because the Romanian form does not show -ibil, but rather -abil. This indicates that the adjective was derived from the verb a confunda 'to confound', as suggested by Seche (1960, p. 57), an idea accepted by NDU and DELR.

In other cases, the formal criterion will not allow for a categoric decision in this internal vs external etymology dilemma. For instance, the adjective clientelar '(about relations) based on favours; (about states) that was a client of Rome', cannot be derived directly from Ro. client, as DEX indicated, since there is no suffix - elar in Romanian. However, it could have been derived from clientelă 'clientele', as indicated in SDLR and accepted in DELR, or borrowed from Fr. clientelaire.

Last, but not least, an atypical word formation, be it by affixation or compounding, indicates a loan translation. In the case of less transparent compounds, the loan translation allows etymologists to identify the exact morphemes. Thus, the noun întrajutorare is considered in DEX a compound of intru 'in, within' + ajutorare 'help', although it is attested in the mid-20 ${ }^{\text {th }}$ century (when intru- was no longer productive) and its meaning is 'mutual help'. Therefore, in DELR we considered that intrajutorare is a loan translation of the Fr. entraide, and is made up of intre 'between, among' + ajutorare 'help', the morphemes corresponding to the constituents of the French word.

\section{The semantic criterion}

\subsection{The semantics of the etymon}

Sometimes, the etymon proposed by other academic dictionaries, although acceptable from a formal point of view, does not correspond in meaning with the Romanian word. For instance, for the noun comper 'presenter (of a show), master of ceremonies', DEX indicates Engl. compeer, but this word has a different meaning ('person equal in rank, peer, colleague, comrade'). The Romanian word actually comes from Fr. compere 'godfather' (< Lat. compater), which also developed the meaning 'presenter of a show, master of ceremonies'.

The noun corm 'the entire body of the plants differentiated into roots, shoots and leaves' is registered in DEX as coming from Fr. corme, but this word means 'corm (a short, vertical, swollen underground stem of a plant that serves as a storage organ to enable the plant to survive winter or other adverse conditions such as drought)'. For the concept corresponding to Rom. corm, French uses the form cormus, a scholarly

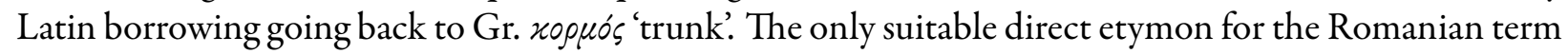

\footnotetext{
${ }^{11}$ See Hristea (1973b, p. 143-155). The author grouped the examples discussed in three main categories: a) Romanian formations that are considered borrowings; b) borrowings that are considered Romanian word formations; c) words with a double origin (both borrowing and Romanian formation).
} 
we could find is It. cormo, which satisfies the meaning criterion (the remote etymon of all these words is the same).

Dacită, the name of a type of explosive, cannot come from Fr. dacite (as claimed by DEX and DLR), which denotes a type of rock and was actually borrowed in Romanian, as a geological term, in the form dacit. We have not been able to identify an external etymon for dacită. Therefore, we believe that it is a trademark created in Romanian, using the-ită suffix, characteristic of names of explosives. Trying to find how this substance (identified by its chemical formula) is called in other languages, we found a different term, Germ. Fördit, a trademark with the same -it suffix.

For the verb delabora, a military term which means 'to disassemble, dismount installations, machines, or ammunition that has become unusable or dangerous', $\mathrm{DN}^{2}$ and $\mathrm{DEX}$ propose borrowing from Lat. delaborare, but this derivative of laborare has the meaning 'to work hard' (the de-prefix does not have a privative meaning here). In any case, borrowing of a modern military term from Latin is totally unlikely. DLR, more cautious, writes "cf. elabora". In fact, the word, with the same meaning as in Romanian, can be found in German: delaborieren, with the abstract noun Delaborierung. This word is derived with the Latin privative $d e$ - prefix from Germ. laborieren 'to assemble an explosive device'. This meaning of the verb laborieren has emerged in German based on the meaning 'to work hard, labour' with which this word was borrowed from Latin (laborare < labor, -öris 'work').

The DEX entry culee brings together two homonyms, providing an etymon that is correct for only one of them. Thus, culee 'abutment; pillar supporting a vault' comes, indeed, from Fr. culée $(<$ cul < Lat. cülus 'butt'), but the meaning 'geat, ledge or hole through which molten metal runs into a mould' cannot be explained from Fr. culée. We are dealing with a different word, unrelated with the first one: it is a borrowing from Fr. coulée (< couler 'to flow' < Lat. cōläre 'to filter' < cōlum 'strainer, vase used for filtering').

The adjective costier was given the correct etymology in $\mathrm{DN}^{2}$ : Fr. côtier, adapted after Ro. coastă 'coast'. DEX proposes Fr. costierre, but this is a noun that denotes various objects or parts of objects (e.g. 'stone frame of an oven or chimney, hollow on the floor of the stage, used for manipulating the scenery').

For the adjective clavicular 'clavicular', DA correctly indicates Fr. claviculaire as the direct etymon, but DEX adds Lat. clavicularius, disregarding its totally different meaning - 'key-keeper, jailer' ${ }^{12}$. The Latin anatomic term derived from clavicula is clavicularis, but given the time when this word appeared in Romanian (the middle of the $19^{\text {th }}$ century) the French etymon is sufficient.

In some cases, we found a semantically closer etymon in a different language, with the same origin as the etymon proposed by previous academic dictionaries. For instance, damă 'rowlock, oarlock; (obsolete) cast iron piece that closes the crucible door in foundries' comes from Fr. dame, which has these very same meanings, rather than from Germ. Damm 'dam', as proposed in DLR (Germ. Damm also fails to comply with the formal criterion: we would have expected the form *dam). The Fr. dame does indeed come from the same Germanic etymon as Germ. Damm (according to TLF, French initially borrowed the Dutch dam with the meaning 'dam', and the metallurgical meaning is either a specialization inside French, or an independent borrowing from Germ. Damm). The 'oarlock' meaning is either a development of the meaning 'dam' (this device prevents the oar from falling into the water) or is a specialization of the homonym dame 'lady, women' (< Lat. domina), based on an erotic metaphor (cf. TLF). Another example is the adjective defect '(about a device) out of action, broken, defective, faulty', whose direct etymon given by DEX, Lat. defectus, is in fact the remote etymon; semantically, the Romanian word perfectly corresponds to Germ. defekt, whereas Lat. defectus, the past participle of deficere, meant 'lacking, deficient, exhausted'. Given the semantic field of the Romanian adjective, mainly technical, Germ. defekt is preferable as a direct etymon.

For borrowings with an ultimate Latin source, Romanian usually displays the same semantic specialization as other modern languages. Dictionaries often give a multiple etymology in which Latin appears

\footnotetext{
${ }^{12}$ This word comes from the original meaning of clavicula, 'little key' (< clavis 'key').
} 
alongside one or more modern languages. This can be justified by the fact that those who introduced the word, knowing its Latin source, adapted its form on the model of Latin (e.g. Ro. afinitate 'affinity' has the exact meaning of Fr. affinité, but formally corresponds to its Latin etymon affinitas, which had more meanings - also 'kinship; vicinity'; therefore, the origin of Ro. afinitate can be considered multiple: Fr. affinité and Latin affinitas, -atis). However, as time went on, certain rules of adapting French words developed, so that it is no longer necessary to assume a Latin etymon, alongside the French one, for the Romanian word. Thus, for the words accelera 'to accelerate', atenta 'to make an attempt on (somebody's life, honor etc.)', atracție 'attraction', capabil 'capable', DELR only kept the French word as a direct etymon, as had proposed $\mathrm{DA}$ and CADE, rejecting the addition of a second Latin etymon, given that the Latin words had a wider or more concrete meaning (accelerare 'to speed up', attentare 'to try', attractio 'drawing towards oneself, drawing together, contraction', capabilis 'that can contain, receive, comprehensible'). For some words the semantic distance between the Romanian and the Latin term is considerable, due to an evolution that took place inside French: thus, for agapă 'feast, banquet' and capitula 'to capitulate, surrender' the meanings found in Romanian have appeared in French; Lat. agape, a Christian term borrowed from Gr. $\dot{\alpha} \gamma \alpha \dot{a} \pi \eta$ '(brotherly) love, affection', meant 'Christian love; charity; charity meal; common meal of the early Christians, at which the sacrament was performed'; Lat. capitulare meant 'to enumerate, make a report point by point, stipulate in a convention, agree' (< capitulum 'article, paragraph'). Therefore, adding Lat. agape and capitulare to the French etyma is not justified.

\subsection{The semantic criterion as an argument against derivation in Romanian}

In some cases, the semantic criterion made us reject a Romanian-internal origin and adopt a foreign etymon instead. The clearest case is the one in which the meaning associated to the purported Romanian derivational affix cannot explain the meaning of the word at hand. Thus, DLR treats the transitive verb demagogiza as derived from demagog 'demagogue' with the -iza suffix. But if this were the case, we would expect the meaning 'to turn somebody into a demagogue', a meaning not found in the attested example. The verb, rare and obsolete, means something totally different, namely 'to try to influence people by a demagogic behaviour, to manipulate' (in the Eminescu example cited by DLR, demagogizarea locuitorilor săteni 'the demagogization of the rural inhabitants' does not refer to transforming the peasants into demagogues, as would follow from the meaning indicated by DLR for the abstract demagogizare, but, obviously, to their manipulation by demagogic means). This meaning is found for the Ancient Greek verb $\delta \eta \mu \alpha \gamma \omega \gamma \varepsilon \tilde{i v}$, where it arose naturally from the basic meaning 'to lead the people', as a specialization going hand-in-hand with the pejorative specialization of the nominal base $\delta \eta \mu \alpha \gamma \omega \gamma$ 's "leader of the people, of the demos; demagogue"13. Consequently, we proposed for Ro. demagogiza either a cultural borrowing from Ancient Greek, or from German, where a verb demagogisieren with this meaning has some sporadic attestations. The occurrence of the word in Eminescu supports borrowing via German, but the rarity of the German word made us consider a direct Greek source equally possible.

Other examples of this type concern the prefix $d e-$, which is productive in Romanian only with what we call a "privative" meaning: 'to bring out of a state, to remove, to make a transformation in the opposite direction with respect to the base verb'. DLR treats as Romanian derivatives a number of words where $d e-$ does not contribute this meaning. We are actually dealing with borrowing. Thus, the obsolete verb delucida 'to explain, clarify' comes from It. delucidare and scholarly Latin delucidare, a late derivative of lucidus 'bright, clear' on the model of dilucidare, elucidare; Ro. delucida cannot come from de- + elucida 'elucidate', as proposed in DLR. Likewise, the rare and obsolete verb depreda 'to plunder; (about plants) to destroy' is a borrowing from Lat. depredari (< predari 'to plunder' < preda 'booty') (DLR indicates here "Cf. prăda"). The adjective degenerator 'that provokes degeneration; degenerative' cannot come from generator 'generator' as indicated in DLR, but is borrowed from Fr. dégénérateur, a rare word attested in

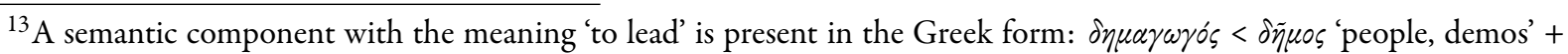

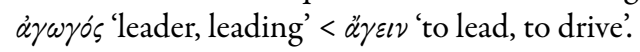


Ion Giurgea, Cristian Moroianu \& Monica Vasileanu

the $19^{\text {th }}$ century with the meaning 'degenerative' (it is a derivative of the verb dégénérer 'to degenerate') ${ }^{14}$. The verb derîde 'to mock', for which DLR proposes de- + rîde 'laugh', is in fact a back formation from the abstract noun derîdere 'mockery', which is much more frequent and has an external source: it is a partial calque from Fr. dérision, with the adaptation of the root after the inherited verb rîde 'to laugh' (< Lat. ridere) and the replacement of the nominal suffix - sion with the productive Romanian suffix $-r e^{15}$. Fr. dérision itself is a borrowing from Lat. dèrisisio, the abstract of dèrìdère 'to mock' (< rìdère 'to laugh'). As we can see, the affixation of $d e$ - actually occurred in Latin, the remote source of the Romanian word.

We also encountered situations where the purported base does not have a suitable meaning: for the adjective and noun digitalic '(medicine) based on digitalis', DLR proposes a derivation from digital, but both adjectives digital registered in DLR, 'pertaining to fingers' and 'digital (in informatics)' do not correspond semantically; there is in fact a third possible base, digitala ' the plant digitalis', which is appropriate from a semantic point of view, but due to the technical character of the verb, we opted for Fr. digitalique.

In most of the cases in which we rejected a Romanian source, the semantic criterion was combined with the historical criterion: words which belong to specialized technical fields, international scientific or technical terms are most likely to be borrowed, because these fields first developed in other countries and were adopted by Romanians by cultural contact. Thus, for africanologie 'study of African cultures and languages' a borrowing from Fr. africanologie is more likely than the derivation from Africa given in DEX; cheiaj 'docking of a ship at a wharf; wharfage (tax), quayage' comes from Fr. quayage, as indicated by SDLR, rather than from Ro. chei 'wharf', as claimed by DEX; the geometry term conciclic 'concyclic' must come from Fr. concyclique ( $\mathrm{CADE}$ ), rather than being derived from con- and ciclic (DEX); for combinor 'combiner in a telephone exchange' we chose Fr. combineur, rejecting the derivation from Ro. combina 'to combine' supported by DEX; the adjective curant used in the collocation medic curant 'attending physician' is most likely borrowed from It. curante, rather than derived from Ro. cura 'to treat a patient', as proposed in DEX. Other examples of this type are: cristalinitate 'degree of crystallisation of an eruptive rock' (DELR: Fr. cristallinité, germ. Kristallinität; DEX: from Ro. cristalin); cristalizator 'crystallizer' (DELR: Fr. cristallisateur; DEX: from Ro. cristaliza); decarbonizație (obsolete) 'the elimination of carbon dioxide from blood' (DELR: Germ. Dekarbonisation, Fr. décarbonisation; DLR: from Ro. de- and carbonizație), and a number of compounds: cerebrastenie 'brain asthenia' ( $\mathrm{DN}^{3}$, DELR: Fr. cérébrasthenie; DEX: from Rom. cerebr(al) and astenie), exocortex (botanic term) 'exocortex' (DELR: Engl., Fr. exocortex; DLR: from Ro. exo- and cortex), fotocromatic 'photochromatic' (DELR: Fr. photochromatique, Engl. photocromatic; DEX: from Ro. fotocrom and-atic, a derivation that is spurious, since the two adjectives fotocrom and fotocromatic are synonymous, and also improbable, because the suffix - atic does not attach to modern cultural bases; in this word, the segment -at- originates in the base, which is the Greek word $\chi \rho \tilde{\omega} \mu \alpha$, $\chi \rho \omega \mu \alpha \tau \tau \varsigma_{5}$ 'color'), paraclinic '(about medical investigations) paraclinical, using other methods than the direct observation of the patient' (DELR: Fr. paraclinique, DEX: from Ro. para -+ clinic), pedoclimatic 'pedoclimatic, pertaining to the microclimate of the soil' (DELR: Fr. pédoclimatique, Engl. pedoclimatic; DEX: from Ro. pedo- + climatic), pluricarpelar adj. (botanical term) 'formed by several carpels' (DN ${ }^{3}$, DELR: Fr. pluricarpellaire; DLR: from Ro. pluri- + carpela $+-a r)$, policromat 'multicoloured, made of materials of various colours' (DELR: Fr. polychromé; DEX: from Ro. policrom), portclișeu (photography) 'small box in which negatives are kept' (DELR: Fr. porte-cliché, adapted after clişeu 'negative; stereotyped plate'; DEX: from Ro. port- ${ }^{1}$ and clişeu), pseudococaină 'pseudococaine' (DELR: Fr. pseudococaïne, Engl. pseudococaine; DLR, DEX: from Ro. pseudo- + cocaină 'cocaine'), tetracarbonil 'tetracarbonyl' (DELR: Fr. tétracarbonyle (de nickel), Engl. (nickel) tetracarbonyl; DLR: from Ro. tetra- + carbonil), topoclimatologie 'topoclimatology' (DELR: Fr. topoclimatologie, possibly also Engl. topoclimatology; DEX: from Ro. topo- + climatologie).

\footnotetext{
${ }^{14}$ Borrowing from French is supported by the time of the first attestation of the Romanian word: 1862, Pontbriant, D.

${ }^{15}$ Romanian also borrowed Fr. dérision in the form deriziune. The words derîdere and deriziune represent a synonymic pair made of a calque and a borrowing. See Stanciu-Istrate (2006, p. 147, 299), Moroianu (2016, p. 265).
} 


\subsection{The semantic criterion as an argument for derivation in Romanian}

Although much less frequent, situations in which the meaning criterion supports derivation in Romanian against borrowing can be found. Thus, cuplă 'demountable device for connecting two vehicles (usually in railways) or two elements of a technical system' cannot come from Fr. couple, as indicated in DEX, because couple lacks this technical use, meaning only 'couple' (both as a masculine and as a feminine noun, the latter being an obsolete variant). Therefore we treated Ro. cuplă as a back formation from the verb cupla 'to interlock, wire, couple.' The adjective precaut 'cautious' does not correspond semantically to the Latin etymon precautus given by DLR and DEX, which had a passive meaning 'which has been taken care of'. Therefore we considered it as a back formation from precauţie 'caution'. For calcio-vecchio 'type of ornamental plaster', the form suggests an Italian origin, so that it is not surprising that DEX considered it an Italian word. But we have not been able to find an expression with this meaning in Italian. Treccani registers three Italian words calcio: calcio ${ }^{1}$ 'heel' (< Lat. calx); calcio 'kick with the foot; football; hit at the billiard game' (< calciare 'to kick (with the foot)' < calcio ${ }^{1}$ ), calcio $^{3}$ 'calcium' (a learned borrowing from Lat. Calcium, a derivative of calx 'chalk'). We do not dispose of sufficient information about the history of this plaster type and its denomination, therefore the solution adopted by DELR is given with a mark of uncertainty ('probably'). In the absence of an ascertained external source, we considered Ro. calcio-vecchio as a false Italianism created in Romanian, using erroneously a masculine calcio instead of the feminine calce 'chalk', triggering masculine agreement on the adjective vecchio 'old'.

\section{The chronological criterion}

For modern cultural borrowings, a frequent problem is the existence of more than one possible source. Establishing the date when the word entered Romanian is one of the methods that can be used to decide between multiple possible sources. Disposing of a larger corpus, with a lot of digitalized old texts, where automatic word search is possible, we have been able to correct a number of previous etymologies, based on attestations which are either too old or too new for the solutions given by the previous dictionaries. Thus, the noun and adjective calvin 'Calvinist' cannot come from Fr., as given by DA, because it occurs already in 1600, in a document from Transylvania (Doc. Î. XXXII), and continues to be attested during the old Romanian period (in Varlaam, Miron Costin, Dosoftei, Axinte Uricariul, in Îns. ms., etc.). It is in fact a borrowing from Lat. calvinus, which had a common noun and adjective use. For crenel 'crenel', attested already in 1839 (Negruzzi, O. II, 172), the correct etymon is the one given by DA, CADE, CDER 2557, namely Fr. créneau, with an etymological reshaping of the -eau suffix (Old Fr. crenel) supported by the derivatives Fr. créneler, crénelé. DEX, based on the form, proposes Engl. crenel, but this is unlikely for the first half of the $19^{\text {th }}$ century. Sometimes our attestations indicate a time posterior to the French influence: thus, the verb clica 'to click (on a computer), to select an icon by pressing the mouse', which entered Romanian together with personal computers and graphic interfaces such as Windows, is obviously either a borrowing from Engl. to click or a Romanian derivative of the noun clic 'click', used in the expression a face clic. The French etymology (cliquer) proposed by DEX is highly unlikely.

The chronological criterion also involves the diffusion of the purported etymon in the source language at the time of the borrowing. Thus, in the case of the word xerocopie, attested in $1966\left(\mathrm{LTR}^{2}\right)$, the etymons proposed by DLR (Fr. xérocopie, It. xerocopia) cannot be found before 1966, so the information available to us rules them out. Older attestations are only available for Engl. xerocopy (e.g., in the Photographic Engineering Review, 6-7, 1955, p. 257, 258). Consequently, we proposed an English etymology. The term was probably coined in English, based on xerography $(<x e r o-<$ Gr. $\xi \eta p o ́ s ~ ' d r y '+-g r a p h y)$ and copy.

In many cases, the chronological criterion led to the rejection of derivation inside Romanian, in favour of borrowing. For instance, DLR treats the obsolete verb excontentelui 'to pay a compensation', used in Transylvania, as coming from Ro. excontenta (with the same meaning), for whose etymology a relation with esconta is indicated ("cf. esconta"). But excontentelui is attested, in the variant escontentelui, already in 1806 (Iorga, S. D. XII), well before excontenta for which the first available attestation is 1844 (Barițiu, C. 
IV, 196). In fact, we are dealing with two variants of adaptation of the Latin verb excontentare. There is no derivational relation between these variants. A similar situation is found with the obsolete adjectives danic and danicesc 'Danish', considered by DLR as derivatives of dan 'Dane'. They should rather be considered as borrowings from Lat. danicus, Modern Gr. Savixós, because of the time when they are attested-1829 (AR, 95) for danicesc and 1842 (Asachi, L. 16) for danic-, a period when the suffix -ic-was in the process of entering Romanian, via borrowings, and was often adapted in the form -icesc (hypercharacterized with the native adjectival suffix - esc). The latter adaptation precedes the borrowing of the suffix in the form $-i c$.

The words demofil 'demophile, friend of the people' and demofilie 'demophilia' are attested at roughly the same time: demofil in 1936 (Crainic, P. card. 48), demofilie in 1935 (Diamandi, O. P. 188). Therefore DLR's proposal that the latter is a derivative of the former is not supported. More likely, the whole word family was borrowed from French (démophile, démophilie).

The chronologic criterion coupled with the concept history criterion indicates an external source for a number of derivatives of place names for which other academic dictionaries propose derivation in Romanian. If the toponym refers to a place unfamiliar to Romanians in the period of the first attestation and the suffix was not productive in Romanian at that time, we must assume that the word is a borrowing. For instance, african 'African', attested already in the $17^{\text {th }}$ century $(1682$, Dosoftei, V. S., octombrie, $\left.87^{\mathrm{r}}\right)^{16}$, cannot be derived from Africa with the suffix - an (which was not productive in Romanian at

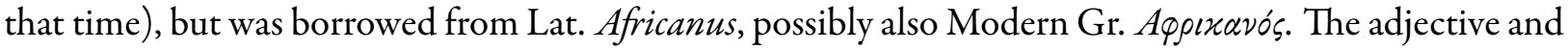
noun chinez 'Chinese' cannot be derived in Romanian from China, because it is attested in 1830 (Iancu Văcărescu, "Tipografia”), at a time when the $-e z$ suffix was just entering the language via borrowings. This ethnonym was borrowed from Western languages (It. Cinese, Germ. Chinese, Fr. Chinois) and its initial part was modified after China. The adjective chinezesc, attested a little earlier, in 1802 (Amorven și Zalida, romanțchinezesc, translated from French, probably by Alecu Beldiman, cited in Ursu \& Ursu, 2011) contains the element -ez- that cannot be explained by derivation in Romanian; it represents an adaptation of the Western ethnonym, with -esc- marking the adjectival status (cf. -icesc discussed above). Likewise, for caucazian 'Caucasian', attested in 1848 (Brezoianu, Î. 113), borrowing from Fr. caucasien is preferable to the derivation from the toponym Caucaz given by DEX.

A similar case is the adjective chirilic 'Cyrillic', for which DA and DEX indicate the proper name Chiril 'Cyril' as the direct etymon. The noun appears already at the beginning of the $19^{\text {th }}$ century, in the form cirilic, in Petru Maior's Dialogu pentru începutul limbei română, published in 1819. In the same text we encounter the forms cirilicesc and chirilicesc. As by this time the suffix -ic was entering the language via borrowings, it is clear that this adjective was not derived in Romanian, but borrowed from Lat. cyrillicus. Petru Maior had used in a previous text, published in 1812, Dissertație pentru inceputul limbei românești, the adjective cirilian, borrowed from Lat. cyrillianus. Another form that we encounter in the beginning of the $19^{\text {th }}$ century is tirilicesc, in the 1834 translation of a Latin text of Petru Maior (see Maior, S. II 209), which may be come from Lat. cyrillicus (with the central European pronunciation of Latin) or from Germ. cyrillisch.

A special case where the chronology of attestations is helpful concerns technical terms denoting activities, which occur both as verbs and names of actions. Although, from a formal and synchronic point of view, the noun usually appears as a derivative of the verb, from the historical point of view things may be reversed: sometimes, the term first enters the language as a noun in which the suffix in the source language is replaced with the corresponding Ro. suffix $-r e^{17}$; subsequently, the corresponding verb is created, as a back formation. Let us see a number of examples where the available attestations support a history of this type, refuting the derivation of the noun from the verb indicated in DEX: climatizare 'air conditioning' is attested already in $1949\left(\mathrm{LTR}^{1}, \mathrm{I}\right)$ and is more frequent than the verb climatiza, attested as late as 1978

\footnotetext{
${ }^{16}$ A little time before, in Let. cantac. (1665-1672), the word appears as part of a proper name, Sțipio African.

${ }^{17}$ See a lot of examples in Carabulea \& Popescu-Marin (1967, p. 277-320). Bogdan-Oprea (2011, p. 96-97) discusses this issue in the context of the "relatinisation of Romanian". For the concept of "suffix correspondence/equating" (echivalare sufixală), in relation to substitution and linguistic calque, see Moroianu (2017, p. 335-347).
} 
$\left(\mathrm{DN}^{3}\right)$, which made us explain climatizare as an adaptation of Fr. climatisation; cobaltare 'covering the surface of a metallic object with cobalt', attested in 1949 ( $\left.\mathrm{LTR}^{1}, \mathrm{I}\right)$, well before cobalta $\left(1978, \mathrm{DN}^{3}\right)$, was considered a borrowing from Fr. cobaltage (as also proposed in $\mathrm{DN}^{3}$ ) and Germ. Kobaltierung, with suffix replacement; colectivizare 'merging of individual rural properties into a collective enterprise (imposed by communists)', attested in 1948 (Contemp. nr. 109, 4/2), before the verb colectiviza (attested in 1953, Cursul scurt de istorie a PCUS, cited in DLRLC) and used more frequently than the verb, was considered a borrowing from Ru. kollektivizacija.

\section{The etymon frequency criterion}

For words belonging to the specific terminology of various scientific and technical fields, the source language is often hard to identify and the existence of more source languages is plausible. Thus, alongside French, we must take into account German, English, and, for a specific period, Russian. The recent academic dictionaries (DEX and DLR) give priority to French, except for the very recent borrowings, where English begins to be mentioned. This priority is undoubtedly justified by historical facts (French was the international language of culture best known in Romania until the last decades of the $20^{\text {th }}$ century), but in some cases it was pushed too far. Some French etymons proposed by recent dictionaries are either extremely rare or plainly unattested. In our work for DELR, after checking the etymon in the French reference dictionaries (TLF, Robert, Larousse), we proceed by verifying the existence of the term in the sources available online-various technical dictionaries, Wikipedia, web pages written in French-giving priority to the search in books ${ }^{18}$ and restricting the search to the period which precedes the first attestation of the word in Romanian. The same procedure is applied to other possible source languages.

First we present a number of cases where the etymon proposed by DEX and DLR could not be attested at all (these are all purported French words, with one exception, see crib below). The following sub-types can be distinguished:

(i) The word actually comes from another language: calcocloroză 'chlorosis due to the shortage of iron in the soil' was formed from calco- and cloroză 'chlorosis' on the model of Germ. Kalkchlorose (DEX: Fr. chalcochlorose); chemitipie 'technique of stereotype engraving, based on chemical procedures' < Germ. Chemitypie (DEX: Fr. chémotypie); citocromie 'rapid printing procedure using four superimposed colours' < Germ. Citochromie, a word coined by the German engineer Eugen Albert from Lat. citus 'quick' and Gr. $\chi \rho \tilde{\omega} \mu \alpha$ 'colour' (DEX: Fr. cytochromie); climostat 'device for measuring the thermic effect of climatic factors on buildings' < Germ. Klimostat, Rus. klimostat (DEX: Fr. climostat); crib 'water crib' < Engl. [water] crib (DEx: Germ. Kribbe; this is in fact a Dutch and Low German word; the standard German form is Krippe); cromoalgrafie 'algraphy used for multicoloured printing moulds' < Germ. Chromoalgraphie (DEX: Fr. chromoalgraphie); delint 'delint (noun)' < Engl. delint (DLR: Fr. délint);

(ii) The word was in fact created in Romanian: canisă 'dog-breeding farm' was probably coined on the base can (i)- 'dog' found in canin 'canine', canid 'canid' (DEX: Fr. canice); celaperm 'fibre obtained by a chemical procedure from cotton cellulose' was probably composed of cel(a) - (<celuloză 'cellulose') + -perm (<permeabil 'permeable') (DEX: Fr. celaperm); celofibră 'artificial fibre obtained from cellulose' < celo- $(\leftarrow$ celuloză 'cellulose') + fibră 'fibre' (DEX: Fr. cellofibre); carpatin 'belonging to the Carpathian mountains' < Carpați 'Carphatians' (a solution already given in DA and CADE; DEX: Fr. karpathin);

(iii) The word exists but has a different form: corona 'corona (effect)' < Fr. (effet) corona, Engl. corona (DEX proposes Fr. coronne, a form that does not exist, and Germ. Krone, which does not correspond in meaning-it just means 'crown'; for corona, the compound Koronaentladung is used); decozină 'delcosine' < Fr., Engl. delcosine, a word created based on the name of the plant from which this alkaloid is extracted, Delphinium consolida (DLR: Fr. décozine).

\footnotetext{
${ }^{18}$ To this end, we use the "Books" setting of Google.
} 
Ion Giurgea, Cristian Moroianu \& Monica Vasileanu

We now present a number of cases where an etymon was rejected because it has very few attestations in the purported source language:

(i) The word actually comes from another language: astroclimat 'astroclimate' < Engl. astroclimate, Rus. astroklimat (DEX: Fr. astroclimat); caracterograf 'electronic device that displays the features of the semiconductor devices on the screen of a cathode ray tub' $<$ Rus. charakterograf (DEX indicates Engl. characterographe (sic!); a form characteograph appears indeed in English, but seems to be very rare); catometru 'cathometer' < Germ. Kathometer, Engl. cathometer < cathode + -meter (DEX: Fr. catomètre); cenotip 'coenotype' < Engl. coenotype < coen- < Gr. xoıvós 'common' + type (DEX: Fr. cénotype). For the noun cvartet 'quartet', It. quartetto indicated by DA, CADE, SDLR, CDER and DEX is an acceptable etymon, but DEX adds Fr. quartette, which is unlikely given its very low frequency in French (the usual term is quatuor); in addition to Italian, it is very likely that the Romanian word also has a German source, Germ. Quartett.

(ii) The word was actually created in Romanian: dedentiție 'loss of teeth' < de- + dentiție 'dentition' (the Fr. dédentition indicated by DEX and DLR is extremely rare; the privative derivatives of the base dentin French show the prefix é-: édenter etc.); dendrometrist 'specialist in dendrometry' < dendrometrie 'dendrometrist', with suffix substitution (DEX, DLR: Fr. dendrométriste); hidrocosmetică 'cosmetics that uses water and moisturizing products', probably formed in Romanian from hidro- 'hydro-, water' + cosmetică (the Fr. hydrocosmétique proposed by DEX is extremely rare and only occurs as an adjective, spelled hydro-cosmetique).

(iii) The word is a structural calque: bioamplificator 'bioamplifier', attested in 1988 (DEX-s), is composed of bio- and amplificator 'amplifier', copying Engl. bioamplifier. DEX proposes Fr. bioamplificateur, but this is a rare word for which we could not find attestations preceding the first attestation of the Romanian word.

Sometimes the diffusion of the alleged etymon in the source language is restricted to a period or a region for which there is no contact with Romanian. Thus, for advent, 'advent', alongside Lat. adventus indicated by DEX and Germ. Advent indicated by MDN, both acceptable, DEX adds Fr. advent. But this is an obsolete form that disappeared after the $17^{\text {th }}$ century, the current form being avent. For adaptor 'adaptor', DEX gives Fr. adapteur but this is a recent borrowing from English that is used mostly in Canada. The real origin of the word is Engl. adaptor/adapter. Contractor 'contractor', attested already in 1813 (Doc. Orh., 463), initially came from Germ. Kontraktor and Rus. kontraktor, and nowadays it was revived or reintroduced by the contact with English. The etymon indicated in DEX, Fr. contracteur, is unacceptable because it is a recent English borrowing in French. The obsolete verb defensa 'to protect, to defend', attested in 1848 (Negulici, V.), was introduced in Romanian in order to create a lexical family based on the Latin verb defendere (in the same period we find the verbs defenda, defende 'to defend', the nouns defensă, defensie 'defence' and the adjective defensibil 'defensible'); in this case, the frequentative Latin verb defensare was used, probably because it was formally closer to the abstract noun defensă. DEX proposes Fr. défenser, but this verb had gone out of use well before the $19^{\text {th }}$ century (according to TLF, this verb is limited to Middle French).

\section{The concept history criterion}

For neologisms, this criterion is mainly used for the remote etymology, being involved in establishing the language where the term appeared for the first time. There are nevertheless a few situations where it proved relevant for the direct etymology.

Thus, we encountered two examples of learned compounds created in Romanian for which the academic dictionaries, influenced by the usual situation of cultural neologisms, proposed foreign etyma: the adjective and noun calofil '(author) who is concerned above all with the beauty of the literary expression (disregarding the content)' was created by the Romanian writer Camil Petrescu based on Gr. $\varkappa \alpha \lambda$ ós 'beau-

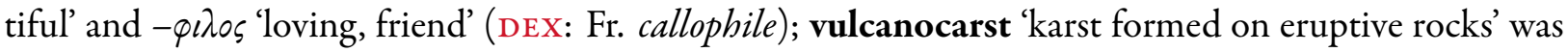


created by the Romanian geologist T. Naum in order to refer to a geological phenomenon specific to the Călimani mountains (DLR: Rus. vulkanokarst).

The noun crotálie 'small metal plate applied on the ear of animals as a sign of recognition' for which

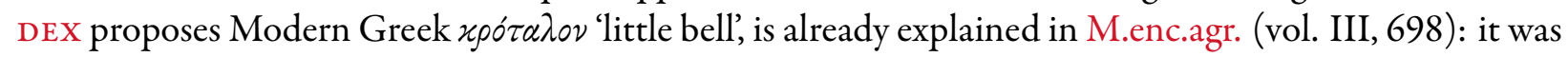
a trademark, Crotalia, introduced by the German company Hauptner in 1887, based on Lat. crotalia (pl.

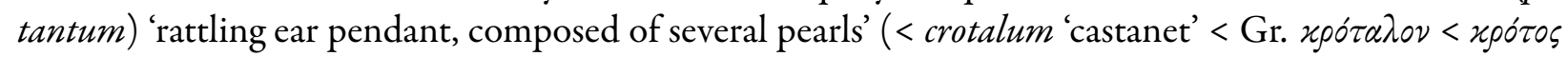
'rattling noise, clapping of the hands, applause').

For deculator 'deculator, device used in the paper industry for removing air from paper pulp', DLR proposes Fr. découleur, a word unattested with this meaning (it is extremely rare and does not occur in the relevant technical contexts). The word actually comes from Engl. deculator, a trademark introduced by the Clark \& Vicario Corp., coined on the name of the inventor of the device, the American chemical engineer Judson Albert De Cew.

For trademarks, it is reasonable to assume that the name of the product enters the language alongside the imported product itself, being inscribed on the product or on the pack. Therefore, for a word such as corhart 'refractory aluminium-based material, used in lining the ovens for the manufacture of glass', a product of the English company Corhart Refractories (formed in the years 1920 by the association of the Corning Glass Works and Hartford Empire companies ${ }^{19}$ ), it is more plausible that Romanian engineers adopted the English trademark directly rather than via another language. Therefore we rejected the solution proposed by DEX, Fr. corharte (it must be noticed that a Fr. form in $-e$ is unattested, the word was used in French only in the form corhart).

\section{Words for which no etymon has been proposed before}

There are a few neologisms for which no etymon has been proposed in the academic dictionaries or the dictionaries of neologisms (such words are marked with "et. nec." in DEX and DLR). For the following examples, an etymological solution was first provided by DELR:

(i) caprotină 'Caprotina (fossil genus of Cretaceous bivalve molluscs)' < Fr., Engl. Caprotina, name given by the French biologist Alcide d'Orbigny in 1842, coined on the related genus Caprina;

(ii) chenaf 'kenaf (the plant Hibiscus canabicus)' < Fr. kénaf < Pers. kenaf (related to Lat. cannabis = Ro. cînepă, Engl. hemp, etc.);

(iii) ciumiză 'the plant Setaria italica-maxima' < Rus. ćumiza (< Chinese choumizi, according to ESUM);

(iv) coleí 'to remove the hair from a hide, using depilatory substances', probably from Fr. coller 'to glue', as the paste used in the process sticks to the hide.

(v) cupíu (rare) 'unit of payment (e.g. bill) in which an amount of money is divided', attested in DOOM ${ }^{1}$ and included in DEX, is in fact a singular form created by the false segmentation of the plural cupiuri of the noun cupiură (with accent shift: cupiúră, pl. cupiưri > cupiuri > sg. cupiu); cupiură, which has the same meaning, is a variant of the noun cupúră, a French borrowing (Fr. coupure 'cut, division, way of dividing an amount of money, unit of payment in which an amount of money is divided' < couper 'to cut'), with the recommended pronunciation / ku'pyrə/ (this noun occurs in DEX, but its relation with the form cupiu went unnoticed); as Romanian lacks the front rounded vowel $y$, this vowel is often replaced by $i u$ in the language of the people with insufficient proficiency in French or who do not recognize the foreign character of a word (see pedichiură $<$ Fr. pedicure 'pedicure'). The etymology of cupiu was discovered by our colleague Mihaela Morcov, member of the DELR team.

(vi) daourit (pronounced /da.u.'rit/) 'rubellite (a variety of red tourmaline)' < Fr. daourite, created by the French mineralogist Leclerc de Buffon, based on the toponym Daourie, region in Southern Siberia where this mineral was found.

(vii) decelit 'plastic material similar to linoleum' < Germ. Decelith, trademark.

\footnotetext{
${ }^{19}$ The name Corhart was formed by blending the initial segments of the names of the two companies.
} 
Ion Giurgea, Cristian Moroianu \& Monica Vasileanu

\section{Conclusions}

The etymological research nowadays enjoys considerable advantages compared to earlier times, first of all due to the electronic corpora (both on- and off-line) that allow a more detailed study of the moment, the way and the context in which a word was borrowed or derived in a language (with or without external models). The availability of brand new dictionaries and scientific works as well as of a large number of literary or non-literary texts from the past allows us to draw a more accurate picture of the history of words, new and modern as well as old and popular, both in Romanian and in the foreign languages they were taken from. At the same time, these resources raise the standards for the etymological research. The Romanian Academy is meant to provide a standard of research in all the fields of science and the dictionaries issued by it should comply with the contemporary standards of lexicography. The attempt of improving upon previous dictionaries already has a tradition in Romanian lexicology ${ }^{20}$ and should be pursued further, especially in the case of collective works carried out within the same institution. A correlation between the results of the various research groups is necessary in order to avoid perpetuating problematic etymologies. The DELR team is currently working on an updated version of the two already published volumes, which is meant to bring them to the higher standards of the third one. This process inevitably involves corrections, additions and reassessments (concerning meanings, first attestations, sources, variants and etymologies). We aim to develop an online version of the dictionary, which will enable us to permanently update the information, depending on what we may discover during the work for the subsequent volumes of the dictionary. Last but not least, the etymological contributions of our colleagues of other institutes of the Romanian Academy (The "Sextil Pușcariu" Institute of Linguistics and Literary History in Cluj, the "Alexandru Philippide" Institute of Romanian Philology in Iași) are and will be of great help to us.

\section{Bibliography}

\section{A. Dictionaries}

CADE = Candrea, I.-A. \& Adamescu, Gh. (1931). Dicţionarul enciclopedic ilustrat, Editura Cartea Românească, București. CDDE = Candrea, I.-A. \& Densusianu, Ov. (1907-1914). Dicționarul etimologic al limbii române. Elementele latine (A-Putea),

Socec, București.

CDER = Ciorănescu, Al. (2002). Dicționarul etimologic al limbii române, ediție îngrijită și traducere din limba spaniolă de T.

Şandru-Mehedinți și M. Popescu Marin, Editura Saeculum I. O., București.

D.med. = P. Simici (red. responsabil), Dicționar medical, Editura Medicală, București, 2 vol.

DA = Academia Română, Dicționarul limbii române. Sub conducerea lui Sextil Pușcariu. Tomul I. Partea I: $A-B$, Librăriile Socec

\& Co. și C. Sfetea, București, 1913; Tomul I. Partea II: $C$, Tipografia Ziarului “Universul”, București, 1940; Tomul I. Partea

III. Fascicula I: $D-d e$, “Universul”, Intreprindere Industrială a Statului, București, 1949; [Fascicula II: De-desțina; șpalt,

1948]; Tomul II. Partea I: F-I, Monitorul Oficial și Imprimeriile Statului. Imprimeria Națională, București, 1934; Tomul

II. Partea II. Fascicula I: J-lacustru, Tipografia Ziarului “Universul” S.A., București, 1937; Tomul II. Partea II. Fascicula

II: Ladă-lepăda, Tipografia Ziarului “Universul” S.A., București, 1940; Tomul II. Partea II. Fascicula III: Lepăda-lojniță,

Tipografia Ziarului “Universul” S.A., București, 1948.

$\mathrm{DCR}^{3}=$ Dimitrescu, F., Ciolan, Al. \& Lupu, C. (2013). Dicționar de cuvinte recente, ediția a III-a, Editura Logos, București.

DELR = Dicționarul etimologic al limbii române, coordonat de A. Avram \& M. Sala (vol. I, $\mathrm{II}_{1}$ ), I. Giurgea \& C. Moroianu

(vol. $\mathrm{II}_{2}$ ), Editura Academiei Române, București, vol. I, $A-B$, 2011; vol. II, partea I, Ca-cizmă, 2015; vol. II, partea II,

Clac-cyborg, 2018.

DEX = Coteanu, I. \& Mareș, L. (coord.), Dicționarul explicativ al limbii române. Ediția a II-a, Editura Univers Enciclopedic,

București, 1996; reeditat cu adăugiri în 1998, 2009, 2012, 2016.

DÎLR = Chivu, Gh., Buză, E. \& Roman Moraru, A. (1992). Dicționarul împrumuturilor latino-romanice în limba română veche

(1421-1760), Editura Științifică, București, 1992.

DLR = Academia Română, Dicționarul limbii române. Serie nouă. Redactori responsabili: acad. Iorgu Iordan, acad. Alexandru

Graur și acad. Ion Coteanu. Din anul 2000, redactori responsabili: acad. Marius Sala și acad. Gheorghe Mihăilă. București,

${ }^{20}$ See Hristea (Hristea, 1960, p. 235-257; 2007, p. 23-38; 2009, p. 481-498), Avram (1997, 2001, 2006), Loșonți (2001, 2007), Mărgărit (2005, 2010). 
Editura Academiei. Tomul I. Partea a 3-a. Litera D (D-Deînmulţit), 2006; Tomul I. Partea a 4-a. Litera D (Deja-Deținere), 2006; Tomul I. Partea a 5-a. Litera D (Deținut-Discopotiriu), 2007; Tomul I. Partea a 6-a. Litera D (Discord-Dyke), 2009; Tomul I. Partea a 7-a. Litera E (E-Erzaț), 2009; Tomul I. Partea a 8-a. Litera E (Es-Ezredeș), 2010; Tomul III. Literele J, K, Q, 2010; Tomul IV. Litera $L$ (L-Lherzolită), 2008; Tomul V. Litera L (Li-Luzulă), 2008; Tomul VI. Litera M, 1965-1968; Tomul VII. Partea 1. Litera N, 1971; Tomul VII. Partea a 2-a. Litera O, 1969; Tomul VIII. Partea 1. Litera $P(P-P a ̆ z u i)$, 1972; Tomul VIII. Partea a 2-a. Litera P (Pe-Pînar), 1974; Tomul VIII. Partea a 3-a. Litera P (Pînă-Pogribanie), 1977; Tomul VIII. Partea a 4-a. Litera P (Pogrijanie-Presimțire), 1980; Tomul VIII. Partea a 5-a. Litera P (Presin-Puzzolană), 1984; Tomul IX. Litera R, 1975; Tomul X. Partea 1. Litera $S$ (S-Sclabuc), 1986; Tomul X. Partea a 2-a. Litera $S$ (ScladăSemînțărie), 1987; Tomul X. Partea a 3-a. Litera S (Semn-Sîveică), 1990; Tomul X. Partea a 4-a. Litera S (Slab-Sponghios), 1992; Tomul X. Partea a 5-a. Litera $S$ (Spongiar-Swing), 1994; Tomul XI. Partea 1. Litera S, 1978; Tomul XI. Partea a 2-a. Litera $T$ (T-Tocăliță), 1982; Tomul XI. Partea a 3-a. Litera $T$ (Tocăna-Twist), 1983; Tomul XII. Partea I. Litera Ț, 1994; Tomul XII. Partea a 2-a. Litera $U$, 2002; Tomul XIII. Partea 1. Litera $V(V$-Veni), 1997; Tomul XIII. Partea a 2-a. Litera $V$ (Venial-Vizurină), 2002; Tomul XIII. Partea a 3-a. Litera $V$ (Vîclă-Vuzum) și Literele $W, X, Y$, 2005; Tomul XIV. Litera $Z, 2000$.

DLRLC = Dicționarul limbii române literare contemporane (sub direcția prof. univ. Dimitrie Macrea și acad. Emil Petrovici).

Volumul I: $A-C, 1955$; volumul al II-lea: $D-L, 1956$; volumul al III-lea: $M-R$, 1957; volumul al IV-lea: $S-Z, 1958$,

Editura Academiei, [București].

$\mathrm{DN}^{2}$ = Marcu, F. \& Maneca, C. (1966). Dicționar de neologisme, ediția a II-a, Editura Științifică, București.

$\mathrm{DN}^{3}=$ Marcu, F. \& Maneca, C. (1978). Dicționar de neologisme, ediția a III-a, Editura Academiei, București.

DоOM $^{1}=$ Avram, M. (red. responsabil) (1982). Dicționarul ortografic, ortoepic și morfologic al limbii române, Editura Academiei

R.S.R, București.

ESUM = Mel'ničuk, O.S. (coord.) (1982-2012). Etimologičnyj slovnyk ukrainskoi movy, Nauk, Dumka, Kiev.

Larousse $=$ Dictionnaire de français [online].

LTR $^{1}$ = Lexiconul tehnic român. Bucureşti, Editura Tehnică; vol. I, 1949; vol. II, 1950; vol. III, 1951; vol. IV, 1952; vol. V, 1954, vol. VI-VII, 1955.

$\mathrm{LTR}^{2}=$ Lexiconul tehnic român. Elaborare nouă. Întocmită prin îngrijirea A.S.I.T. de un colectiv sub conducerea prof. Remus Răduleț. Bucureşti, Editura Tehnică; vol. I-II, 1957; vol. III-IV, 1958; vol. V, 1959; vol. VI-VII, 1960; vol. VIII-IX, 1961; vol.X-XI 1962; vol. XII-XIII, 1963; vol. XIV-XV, 1964; vol. XVI-XVII, 1965; vol. XVIII, 1966; vol. XIX „Indice”, 1968. MDA = Micul dicționar academic, Editura Univers Enciclopedic, București. Volumul I: $A-C$, 2001; volumul al II-lea: $D-H$, 2002; volumul al III-lea: $I-P r, 2003$; volumul al IV-lea: Pr-Z, 2003.

MDN = Marcu, F. (2000). Marele dicționar de neologisme. Ediție revizuită, augmentată și actualizată, Editura Saeculum, București.

M.enc.agr. = Filipescu, C. (coord.), Marea enciclopedie agricolă, Editura P.A.S., București. Vol. I, 1937; II, 1938; III, 1940; IV, $1942 ; \mathrm{V}, 1943$.

NDU = Oprea, I., Pamfil, C.-G., Radu, R. \& Zăstroiu, V. (2006). Noul dicționar universal al limbii române, Litera Internațional, București / Chișinău, 2006.

PEW = Pușcariu, S. (1905). Etymologisches Wörterbuch der rumänischen Sprache, I: Lateinisches Element, mit Berücksichtigung aller romanischen Sprachen, K. Winter, Heidelberg.

Robert = Robert, P. (1996). Le Grand Robert de la Langue Française. Dictionnaire alphabétique et analogique de la langue française. $2^{\mathrm{e}}$ édition entièrement revue et enrichie par Alain Rey, Le Robert, Paris, 9 vol.

SDLR = Scriban, A. (1939). Dicționaru limbii românești. (Etimologii, înțelesuri, exemple, citaţiuni, arhaizme, neologizme, provincializme), Edițiunea întîia, Institutul de Arte Grafice “Presa Bună”, Iași.

TDRG $^{2}$ = Tiktin, H., Rumänisch-deutsches Wörterbuch, 2., überarbeitete und ergänzte Auflage von Paul Miron, Otto Harrassowitz, Wiesbaden. Band I, 1986; Band II, 1988; Band III, 1989.

$\mathrm{TDRG}^{3}=$ Tiktin, H., Rumänisch-deutsches Wörterbuch, 3., überarbeitete und ergänzte Auflage von Paul Miron und Elsa Lüder, Clusium, Cluj-Napoca. Band I, 2000; Band II, 2003; Band III, 2005.

TLF = Trésor de la Langue Française. Dictionnaire de la langue du XIX et du XX eiècle (1789-1960). Paris, 1972 ș.u. [online]. Treccani = Dizionario della lingua italiana, pubblicato dall'Istituto dell'Enciclopedia Italiana fondata da Giovanni Treccani e Giunti T.V.P. editori, Firenze, 2014 [online].

\section{B. Books and articles}

Avram, A. (1997). Contribuții etimologice, Univers Enciclopedic, București.

Avram, A. (2001). Noi contribuții etimologice, Univers Enciclopedic, București.

Avram, A. (2006). Comentarii și ipoteze etimologice, Editura Academiei Române, București.

Bogdan-Oprea, H. (2011). Relatinizarea limbii române: privire generală, accepții, delimitări, aspecte, Editura Universității din București, București.

Carabulea, E. \& Popescu-Marin, M. (1967). Exprimarea numelui de acțiune prin substantive cu formă de infinitiv lung și de supin, in "Studii și materiale privitoare la formarea cuvintelor în limba română”, vol. IV, red. resp.: acad. Al. Graur și M. Avram, Editura Academiei, București, p. 277-320. 
Hristea, Th. (1960). Probleme de etimologie in „Dicționarul limbii române moderne”, in "Studii și cercetări lingvistice”, 9 (2), p. $235-257$.

Hristea, Th. (1968). Probleme de etimologie: studii, articole, note, Editura Științifică, București.

Hristea, Th. (1973a). Contribuții la studiul etimologic al neologismelor românești, in "Limba română”, 22 (1), p. 3-15.

Hristea, Th. (1973b). Criterii de diferențiere a formațiilor interne de imprumuturi, in "Analele Universității din București. Limba și literatura română", 22 (1), p. 143-155.

Hristea, Th. (2007). Etimologia în principalele lucrări lexicografice românești. Considerații critice, in Pană Dindelegan, G. \& Stoica, G. (coord.), "Limba română. Stadiul actual al cercetării. Actele celui de al 6-lea Colocviu al Catedrei de limba română (29-30 noiembrie 2006)”, Editura Universității din București, București, p. 23-38.

Hristea, Th. (2009). Considerații pe marginea unui dicționar etimologic: CDER, in "Limba română”, 58 (4), p. $481-498$.

Keppel Hesselink, J.M. (2015). The terms 'autacoid', 'hormone' and 'chalone' and how they have shifted with time, in "Autonomic and Autocoid Pharmacology", 35 (4), p. 51-58, Crossref.

Loșonți, D. (2001). Soluții și sugestii etimologice, Univers Enciclopedic, București.

Loșonți, D. (2007). Certitudini și ipoteze etimologice, Editura Academiei Române, București.

Mărgărit, I. (2005). Ipoteze și sugestii etimologice. Note și articole, Editura Academiei Române, București.

Mărgărit, I. (2010). Noi comentarii etimologice și semantice, Editura Academiei Române, București.

Moroianu, C. (2008). Derivarea prin substituție de afixe. Sufixe neologice, in Bejan, D. M., Lucatelli, V. \& Cenac, O. (coord.), "Lexic comun / Lexic specializat. Actele Conferinței internaționale Lexic comun / Lexic specializat, Galați, 17-18 septembrie, 2008”, “Analele Universității Dunărea de Jos din Galați”, Fascicula XXIV, An 1, Nr. 1, Galați University Press, p. 194206.

Moroianu, C. (2009). Derivarea prin substituţie de afixe. Sufixe substantivale vechi, in Saramandu, N., Nevaci, M. \& Radu, C.I. (eds), "Lucrările celui de-al doilea Simpozion Internațional de Lingvistică (București, 28-29 noiembrie, 2008)”, Editura Universității din București, București, p. 281-294.

Moroianu, C. (2016). Motivarea formală a relațiilor semantice. Sinonimia analizabilă, Editura Universității din București, București.

Moroianu, C. (2017). Adaptarea împrumuturilor prin echivalare sufixală, in Stanciu Istrate, M. \& Răuțu, D. (eds), "Lucrările Celui de-al 6-a Simpozion internațional de lingvistică (București, 29-30 mai 2015)”, Editura Univers Enciclopedic Gold, București, p. 335-347.

Sala, M. (1999). Introducere în etimologia limbii române, Editura Univers Enciclopedic, București.

Seche, L. (1960). Cuvinte și sensuri noi în presa actuală, in "Limba Română”, 9 (1), p. 57-65.

Stanciu-Istrate, M. (2006). Calcul lingvistic în limba română (cu specială referire la scrieri beletristice din sec. XIX), Editura Academiei Române, București.

Ursu, N.A. \& Ursu, D. (2011). Imprumutul lexical în procesul modernizării limbii române literare (1760-1860), Editura Cronica, Iași, vol. III, Repertoriu de cuvinte și forme - supliment, 2 părți. 